\title{
Teleradiologi i Norge
}

\author{
Teleradiologi innebærer overføring av radiologisk bildemateriale fra ett sted til et annet for gransking \\ og konsultasjon. Norsk radiologisk forening nedsatte i 2009 en gruppe for å se på muligheter og problem- \\ stillinger knyttet til denne aktiviteten. Vi mener utredningen kan være et godt redskap for dem som skal \\ planlegge tilbudet av radiologiske tjenester i Norge.
}

Utredningsgruppen har gått gjennom norsk lovgivning og redegjør gjennom eksempler hvordan teleradiologi foregår i Norge og i andre land (1). Rapporten munner ut $\mathrm{i}$ et sett av anbefalinger for en velfungerende teleradiologivirksomhet, basert på råd fra European Society of Radiology (2).

Som en del av arbeidet ble det gjort en spørreundersøkelse ved offentlige røntgenavdelinger i Norge. En tredel svarte at de benytter teleradiologi til primærgransking (1). Noen avdelinger sender opp mot halvparten av alle utførte MR-undersøkelser til gransking eksternt. Internasjonalt er teleradiologi en stor virksomhet. Telemedicine Clinic i Barcelona tar hånd om mer enn 250000 undersøkelser per år, og Teleradiology Solutions i Bangalore, India, har 40 radiologer og tilbyr nattevaktstjenester for 75 sykehus i USA (1).

\section{Strengt regulert}

Teleradiologisk virksomhet kan gjennomføres på to prinsipielt ulike måter: Aktører kan sende og motta bilder eller én aktør kan gi en annen aktør innsyn i egen database. Det juridiske grunnlaget for slikt samarbeid er helseregisterloven og helsepersonelloven. Under strenge forutsetninger er det etter helseregisterloven tillatt at ansatte $\mathrm{i}$ et helseforetak kan få innsyn i et annet helseforetaks database. Det må foreligge en eksplisitt avtale mellom foretak og mulighet for loggføring av tilgang, og pasienten må forespørres hver gang det skal gis innsyn. Slike restriksjoner kan medføre at effektivt samarbeid knyttet til teleradiologi blir begrenset. En del forhold er uavklart juridisk: Er det anledning til å sende undersøkelser ut av landet for gransking? Har pasienten i så fall rett til å nekte at hennes bilder blir gransket utenlands?

\section{Supplement}

Teleradiologi er allerede en del av norsk helsevesen og gir mulighet til å opprettholde en desentralisert helsetjeneste med undersøkelser ved små lokalsykehus og distriktsmedisinske sentre der det er vanskelig å rekruttere radiologer. Imidlertid vil vi betone viktigheten av et nært samarbeid mellom kliniker og radiolog. Et røntgensvar er ikke som et laboratoriesvar, det er en visuell tolking av en mengde data. Undersøkelsene må derfor beskrives og tolkes i relasjon til den kliniske problemstillingen.

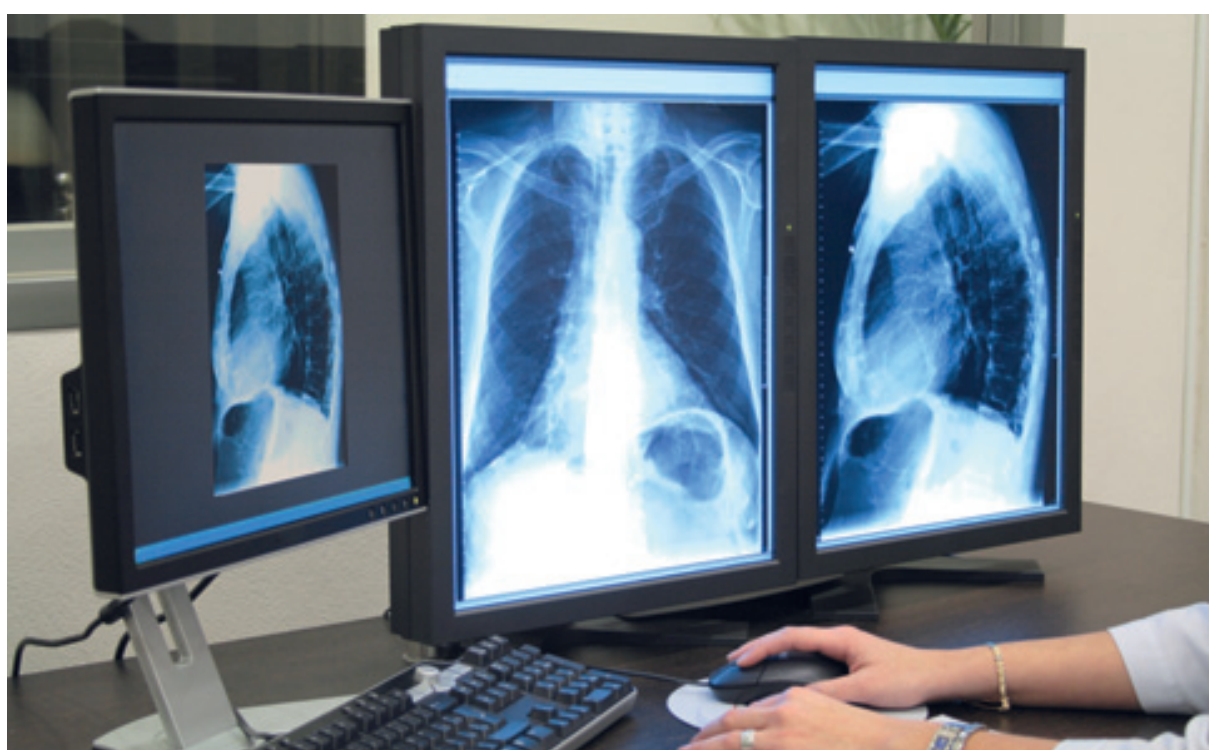

Illustrasjonsfoto Istockphoto

Utvalget vil advare mot å sette ut hele granskningstjenesten til større sentrale granskningssentre. Teleradiologi bør brukes som supplement, ikke som erstatning for et nært samarbeid mellom kliniker og radiolog.

\section{Aslak Aslaksen}

aslak.bjarne.aslaksen@helse-bergen.no Radiologisk avdeling Haukeland universitetssykehus

Institutt for kirurgiske fag

Det medisinsk-odontologiske fakultet Universitetet i Bergen

\section{Roar Pedersen}

Curato Røntgen AS

Oslo

\section{Pål Bache Marthinsen}

Radiologisk avdeling Sykehuset i Vestfold

\section{Nils-Einar Kløw}

Avdeling for radiologi og nukleærmedisin Klinikk for diagnostikk og intervensjon Oslo universitetssykehus

Det medisinske fakultet Universitetet i Oslo

Aslak Aslaksen (f. 1955) er dr.med. og spesialist i radiologi. Han er avdelingsdirektør ved Radiologisk avdeling, og førsteamanuensis ved Institutt for kirurgiske fag. Ingen oppgitte interessekonflikter.
Roar Pedersen (f. 1970) er spesialist i radiologi og er medisinsk sjef ved Curato Røntgen. Han arbeider hovedsakelig med ortopedisk MR. Ingen oppgitte interessekonflikter.

Pål Bache Marthinsen (f. 1972) er spesialist i radiologi og overlege ved Radiologisk avdeling. med særlig interesse for nevroradiologi og erfaring fra prosjektet Tolkningsassistenten, der man evaluerte bruk av teleradiologi for å fjernstyre MR-laboratorier. Oppgitte interessekonflikter: Har mottatt reisest øtte fra Norsk radiologisk forening.

Nils Einar Kløw (f. 1954) er dr.med. og spesialist i radiologi. Han er overlege ved Avdeling for radiologi og nukleærmedisin, professor ved Det medisinske fakultet, og er leder av Norsk radiologisk forening. Ingen oppgitte interessekonflikter.

\section{Litteratur}

1. Aslaksen A, Pedersen R, Marthinsen PB. Teleradiologi i Norge. Rapport fra et utvalg oppnevnt av styret i Norsk radiologisk forening. Oslo: Norsk radiologisk forening, 2010. http:// radiologforeningen.no/img/wysiwyg/File/pdfer/ Teleradiologi\%20i\%20Norge.pdf (20.2.2011).

2. Teleradiology in the European Union. White paper. Wien: European Society of Radiology, 2006. www.myesr.org/html/img/pool/1_ESR_2006_VII_ Telerad_Summary_Web.pdf (3.2.2011). 